\title{
Phenomenology of Friendship: Construction and Constitution of an Existential Social Relationship
}

\author{
Jochen Dreher
}

\begin{abstract}
Friendship, as a unique form of social relationship, establishes a particular union among individual human beings which allows them to overcome diverse boundaries between individual subjects. Age, gender or cultural differences do not necessarily constitute an obstacle for establishing friendship and as a social phenomenon, it might even include the potential to exist independently of space and time. This analysis in the interface of social science and phenomenology focuses on the principles of construction and constitution of this specific form of human encounter. In a "parallel action," the perspective of social science focuses on concrete socio-historical constructions of friendship in different time periods. These findings are confronted with the description of principles of the subjective constitution of the phenomenon of "friendship" from a phenomenological perspective. The point of reference for the study is the real type of the symbolically established and excessively idealized form of friendship intended for eternity which was especially popular in eighteenth century Germany. Analogous to the method of phenomenological reduction, three different levels of protosociological reduction are developed for the exploration of the unique social phenomenon of friendship.
\end{abstract}

Keywords Friendship - Construction · Constitution · Symbol · Edmund Husserl · Thomas Luckmann

What is a friend? A single soul dwelling in two bodies.

-Aristotle: Nicomachean Ethics

J. Dreher ( $($ )

Social Science Archive Konstanz, University of Konstanz, Fachbereich Geschichte und Soziologie,

Fach 35, 78457 Konstanz, Germany

e-mail: Jochen.Dreher@uni-konstanz.de

URL: http://www.uni-konstanz.de/soziologie/archiv2/ 


\section{The Phenomenon of Friendship}

Like no other form of human encounter, friendship establishes a particular bond between human beings in which the subjectivity of the individual actor is involved in a specific manner. A variety of philosophical writers from different epochs focused on this social phenomenon and highlighted the importance of analyzing this unique form of human encounter. As far as social science is concerned, far less significance has been given to the investigation of the social relationship of friendship. And if we focus on the phenomenological tradition, friendship has been almost neglected, if we accept some brief reflections on the phenomenon in relation to mundane phenomenology as an exception (Schutz 1962, p. 353f.). Along with relationships based on love, friendship is notable for the tremendous involvement of the subjectivity of the individual actor. This analysis proposes a specific combination, a "parallel action," of sociological and phenomenological reflection on the construction and constitution of friendship with the aim of describing general principles of the formation of this particular form of social relationship.

First, in order to create the framework of this study on friendship, insights on this phenomenon, especially from ancient philosophy, are presented together with sociological findings. In a second step, the methodical differences between phenomenology and social science are problematized with the intention of establishing a possibility in which both disciplines can relate to each other in a "parallel action" for the analysis of friendship. ${ }^{1}$ With respect to phenomenology, I focus on subjective "constitution processes" of friendship; from a sociological standpoint the socio-historic "construction" of the phenomenon will be examined. The third section concentrates on developing three levels of protosociological reduction analogous to the methodological procedure of phenomenological reduction. On the first level, the socio-eidetic reduction of the construction of friendship is presented; the second reduction focuses on the structural level of the symbolic constitution of "friendship"; the third reduction focuses on the sensual perception of the living body of the other. ${ }^{2}$

In occidental culture, history and in particular, literature, friendship has frequently been the focus of philosophical reflection since Greek antiquity. Friendship was chosen by Aristotle, Cicero, Augustine, Montaigne, and many others as a crucial phenomenon worthy of analysis. Ancient Greek philosophy traditionally distinguished three notions of love that serve to clarify the specificity of the phenomenon of friendship: agape, eros and philia. Agape is a kind of love that does not respond to the antecedent value of its object and is thought to create value in the beloved. Within the Christian tradition, agape has come to mean the sort of love God has for us human beings as well as, by extension, our love for God and our love for humankind in general. Eros and philia by contrast are generally

\footnotetext{
${ }^{1}$ This analysis starts from the assumption that phenomenology and sociology are different paradigms that have to be kept apart from each other because of their diverging methodological standpoints. From this perspective I assume that there is no such discipline as phenomenological sociology (Psathas 1973, 1989; cf. also Eberle 2000).

${ }^{2}$ The exploration of the phenomenon of friendship in a parallel action of phenomenology and the social sciences further develops my reflections on "protosociology of friendship" (Dreher 2008).
} 
understood to be responsive to the merits of their objects-to the beloved's properties, especially their beauty and goodness. Eros is a kind of passionate desire for an object, typically sexual in nature, whereas philia originally meant a kind of affectionate regard or friendly feelings towards not just one's friends but also, e.g. towards family members or one's country at large (Helm 2005, p. 1f.; Cooper 1977). Taking into consideration this classification of different expressions of love, philia is the one specifically relevant for friendship.

The decisive philosophical reflections on the constitution of friendship were presented by Aristotle. In his Nichomachean Ethics he defines three basic kinds of friendship, depending on what it is that binds the one person to the other: friendships of pleasure, of utility, and of virtue. I may love my friend because of the pleasure I get from him or her, because he or she is useful to me in some kind of circumstances, or because I find him or her to have a virtuous character. All three kinds of friendship seem to involve a concern for the friend for his or her sake and not only for one's own. Friendships of pleasure and utility are at best deficient modes of friendship (Cooper 1977, p. 625); by contrast, virtue friendships are genuine and non-deficient because they are motivated by the excellences of one's friend's character (Aristotle 2002, 1155a ff.). Furthermore, it is of major importance for Aristotle that the best sort of friendship appears among virtuous adults and displays not only the acknowledged reciprocation of affection and goodwill but also the reciprocation of choice of one another (Sherman 1987, p. 596f.). In his Eudemian Ethics, he argues:

It is apparent from these things that the primary sort of friendship, that among good persons, requires mutual affection (antiphilia) and mutual choice (antiprohairesis) with regard to one another ... This friendship thus only occurs among humans, for they alone are conscious of reasoned choices (prohaireseis). (Aristotle 1992, 1236b3-6F)

From a sociological perspective, by contrast, friendship has only seldom been researched. As I will argue, the decisive feature for the development of friendships is a personal, voluntary, long-term relationship between two or more people that is emotionally consolidated and as a rule usually exists without sexual obligations and without social control. In his distinction between relations with kin and those with a neighbor, Ferdinand Tönnies describes spiritual friendship as a "kind of invisible location, a mystical city and meeting place which comes alive through the medium of an artistic sympathy or creative purpose" (Tönnies $1887 / 2001$, p. 29). Viewed this way, amicable relationships have the least organic and internally obligatory character; they are the least instinctive and defined less by habit than a deliberate association with one's neighbor. What is thus decisive for friendships is that they constitute spiritual phenomena, which can be traced back either to a coincidence or free selection with regard to their coming about.

Friendship is marked by the fact that this form of relationship is not based on factually determined interests. Rather, it builds on the entire breadth of the personality —at least according to its idea (Simmel 1908/1964, p. 324). In particular the ancient ideal of friendship, which was further developed in the spirit of romanticism, assumes an "absolute spiritual intimacy" and even demands that 
material wealth should be jointly shared by friends. Of core significance in this regard is that the entire, undivided ego becomes involved in a friendship. According to Georg Simmel, this involvement of the ego is more plausible in friendship than in love because friendship lacks the sensual dimension by which love is characterized (1964, p. 325). The present study investigates precisely this particularity of friendship as a form of companionship, which allows for a specific formation of the involvement of the ego and the personality of the individual and establishes a solid, long-term bond between individuals. The design of a combination, or to be more precise, "parallel action" of social science and phenomenological research suitable to this analysis will enable us to describe fundamental, albeit non-universal, principles for the constitution of the phenomenon of friendship.

Determining the interfaces between phenomenology and sociology is not without difficulties, in particular because the two disciplines are different endeavors with regard to their methodological approach and object of research. If one analyzes concrete social phenomena (thus friendship in the present case) while combining both orientations, it is possible to demonstrate how both perspectives refer to each other and can possibly profit from one another. In a "parallel action," considerations of the social constructions of friendship with phenomenological reflections are confronted with the goal of determining the basic principles for the constitution of this specific social relation. "Protosociology," following Thomas Luckmann (1970/ 1983 , 1991), assumes that the analysis of friendship as a form of social relationship must lead back to the level of constitutive conditions of the subjective consciousness as defined within the context of the life-world (Luckmann 1999/2007). From the perspective of consciousness, "friendship" is constituted on the basis of the symbolization of the unique we-relationship of those involved in the social relationship. Along these lines, the performance of consciousness of symbolization (Schutz 1962) proves to be constitutive for the formation of this social phenomenon, which attains an existential status for the individual by means of the process of symbolization.

This analysis of the constitution of the phenomenon of friendship defines, above all, a symbolically established, "excessively idealized" friendship, which is practically intended for eternity, as a reference phenomenon that thrived in particular in eighteenth century Germany. This expression of friendship is therefore taken as the starting point of a systematic development because numerous subcategories of this form of relationship can be derived from it. It is suitable for the analysis because, as a form of long-term relationship, it includes a high degree of individuality of the participants, which is why this type of friendship (in an extreme form of this spiritual and social life) can be systematically used as the foundation for the argument. I assume that the pure life form of friendship can draw on multi-faceted empirical arrangements in order to express itself or to evolve, and one may suppose that these empirical forms are bound by a common meaning (Salomon 1921/1979, p. 282, 1921/2008). Corresponding with the premises of protosociology and the method of phenomenological reduction, I will describe levels of variation and reduction on which the constitutive principles of friendship can be defined. 


\section{On the Parallel Action of Phenomenological and Social Science Research}

At this point we must clarify the crucial differences between phenomenology and sociology in terms of epistemology and discuss how both disciplines can relate to each other in the analysis of social phenomena. From the perspective of a theory of science, basic theoretical reflections that examine how the object of research is constituted are indispensable for sociology. Alfred Schutz took phenomenology to be the most adequate means of philosophically substantiating social sciences when it is assumed that their object of analysis is constituted in human experiences and actions (Schutz 1932/1997, p. 78ff.). His disciple Thomas Luckmann adopts this position and argues that the objective properties of historical social realities are based on the universal structures of subjective orientation in the world. Following his considerations, social science can only be founded upon the principle of “epistemological reflexivity" (Luckmann 1973/1983b, p. 17ff.), which targets the prerequisites of all social science knowledge and focuses on the historical societal reality of the life-world: "The invariable and universal structures of the life-world, which are disclosed by means of phenomenological reduction, form a general matrix for drawing conclusions on human actions" (Luckmann 1983, p. 516). The term "life-world" is understood with reference to its use in Edmund Husserl's Crisis of the European Sciences as "the forgotten fundament of meaning" of science (Husserl 1936/1970, p. 48f.).

In this context, Luckmann devises the project of protosociology: starting with Max Weber's definition of sociology as a science of experience, protosociology is understood as the "phenomenology of the life-world" insofar as it is able to create a link between the universal structures of subjective orientation, the basic forms of intersubjective action, and the objective properties of historical and social realities (Luckmann 1973/1983a, p. 69). However, with regard to their methodological approach both disciplines-phenomenology and the social sciences-have to be decidedly kept apart. Following Luckmann, I use the term "parallel action" ${ }^{3}$ with respect to the interplay between phenomenological and social science research. His considerations demonstrate how a phenomenological analysis of constitution and the reconstruction of historical constructions of reality based on the empirical sciences can complement each other (Luckmann 1999/2007, p. 131). For the phenomenological viewpoint, the concept of "constitution" is crucial since it refers to the constitutive processes of the subjective consciousness that are the basis to build up the individual's world. In contrast, the term "construction" is used from a sociological perspective because it refers the socio-historical expression of a specific phenomenon. ${ }^{4}$ To be more general, it refers to historical human worlds built up in social action.

\footnotetext{
${ }^{3}$ In his novel The Man without Qualities Robert Musil uses the term "Parallel Action" to refer to the planning of the Austro-Hungarian celebrations of the 70-year government anniversary of Emperor Franz Josef in 1918, which were supposed to run parallel to the festivities for the 30-year government anniversary of the Prussian Emperor Wilhelm II the same year (Musil 1995; Berger 1993).

4 The concept of "construction" was principally introduced into the sociological discourse by Berger and Luckmann in The Social Construction of Reality (1966/1987).
} 
The present analysis will draw on several sociological reflections on friendship in order to stimulate thoughts in relation to the constitution of the phenomenon of friendship. In particular, it is decisive to illustrate the constitution of this phenomenon from the perspective of a theory of consciousness. This manner is especially efficient for describing the subjectivity interlinked with this specific form of relationship. Thus, in a parallel action several sociological findings from literature dealing with the construction of friendship are confronted with descriptions of this phenomenon based on constitutive theory. Protosociological considerations on the constitution of friendship are therefore of particular relevance as these reflections explain how the transcendences imposed on individuals by the social world can be "overcome" by the development of this phenomenon. The experiencing subject is confronted with the transcendences or boundaries posed by time, space, the world of the Other, and multiple realities which confront him or her. These transcendences of the life-world of the individual can be overcome with the help of signs and symbols (Schutz 1962, p. 329ff.; Dreher 2003, p. 141ff.; Soeffner $2000)^{5}$; this reflection is of specific relevance for the construction and constitution of friendship. We are searching for the epistemological foundations of the constitution of friendship as a particular form of social relationship.

\section{Sociological Considerations of Friendship}

In highly differentiated societies, relationships between families and relatives and the related roles have lost importance when it comes to providing an all-embracing orientation to human actions (Simmel 1908/1964, p. 317ff.); personal relationships are becoming increasingly important, in particular those based on friendship, because they offer the possibility of individually selecting the potential partner entering into one's life in a certain biographical situation or excluding this partner from an already existing circle of friends. Friendship can be promoted by cultivating similar patterns of thought and requires common development in the areas of typical recognition. The affinities and interests of friends can starkly differ, but in regard to basic dispositions and ideals they must be related (Kracauer 1971, p. 45ff.). Completion and confirmation is found in a friend, i.e. a spiritual and emotional relationship is shared with him or her (Tenbruck 1964, p. 440). Those who rely on themselves in a heterogeneous world discover in friends not only a second self, but also come to discover their own self. This friendship is only substantiated by the fact that two people adjust to one another, and that each person gets an impression

\footnotetext{
5 According to Alfred Schutz's theory of the life-world, the individual's life-world divides itself into the dimensions of time, space, the social world and multiple, everyday transcending reality spheres which form the boundaries or transcendences that the subject has to understand and integrate (Schutz 1962, 1989, p. 159ff.). Signs and symbols represent experiences originating in different spheres of the life-world within the world of everyday life, within which these experiences can be communicated, thereby establishing intersubjectivity. Signs and symbols establish "appresentational systems" with a "meaning clip function" (Srubar 1988, p. 247) that are responsible for the integration of the individual's life-world as a whole.
} 
of the other and lives with this image and at the same time is aware of the fact that the other also lives with such an image of him or her. By concentrating on one another, both friends are committed to each other in these reciprocal and intertwined ways (p. 441). In socio-historical contexts in which traditional social relationships have lost significance, friendships lead to the stabilization of the existence of individuals.

From a phenomenological perspective, following Alfred Schutz, friendship is understood as a notion or idea, an imagined construct, which transcends the world of everyday life of individuals and as a special form of "encounter with fellow human beings," creates a specific bond between people (Schutz 1962, p. 353f.) in everyday life. The experiencing subject is confronted with the transcendences of space, time, the (intersubjective) social world and multi-faceted spheres of reality, the worlds of dream, fantasy, game, religion, sciences, etc. The social world as well as all these multiple reality spheres form part of the subjectively centered life-world of the individual human being. Major significance must be attached to the world of everyday life as a specifically important reality sphere of the lifeworld; as "paramount reality" it is the "world of working" in which physical things including my body are present. I share this world, which is at the same time part of my life-world, with other human beings; within the world of everyday life, "communication and the interplay of mutual motivation becomes effective" (Schutz 1945/1962, p. 226ff.). Social phenomena such as that of friendship or love begin to develop nearly exclusively in face-to-face-relationships while they both are symbolized with a reference to an everyday transcending sphere of reality (Schutz 1989, p. 292f.). In this manner, the social phenomenon of friendship is a long-term establishment and can exist independently of time and space. The fact that one friend lives on another continent in a great spatial distance, for example, does not necessarily impede the social relationship. Also, the friendship can be reactivated after a tremendously long time, after decades, with the idea of a unique friendship still being present, which demonstrates the strength of this specific social relationship. Regardless of differences existing between friends and lovers in terms of time and space, this social relation constitutes a solid, longlasting bond between people.

The phenomenon of friendship usually develops through face-to-face relationships; for both people this involves a high degree of individuality during the encounter with the fellow human being. The social phenomenon appears most frequently in this form of the dyad (Simmel 1908/1964). This analysis of the constitution of the phenomenon concentrates on the "excessively idealized" idea of a unique "friendship intended forever" which appears less frequently, but from which other more cursory friendships such as sports, business or political friendships in gradual deviations can be derived, the elements of which are nearly completely contained in this real-type of friendship. Of course, this type of friendship is the one Aristotle denominated as friendship by virtue. With this commitment to the real-type of friendship intended forever, the constitutive principles of friendship in general can be specified more concretely, because their "extreme form" enables us to illustrate the core characteristics of the social phenomenon. 


\section{Construction and Constitution of Friendship}

From an epistemological perspective, the basic distinction between construction and constitution is of crucial importance for an analysis of the social relationship of friendship. On the one hand, it is assumed that historical human worlds in social actions are constructed. On the other hand, the assumption that reality is constituted on the basis of general structures of experience in activities of consciousness is highly significant. In this regard, phenomenological analysis of constitution falls back on the only direct evidence which is always available to each of us in a Cartesian manner, regardless of what level the sciences have reached-i.e. our own consciousness. By drawing on evidence from pure consciousness, it is possible to reflect on the preliminary assumptions of one's own theoretical activities as well as the human constitution of the empirical object of social sciences (Luckmann 1999/ 2007, p. 128). Accordingly, social phenomena such as the social relationship of friendship can only be constructed in concrete historical worlds. In each of these social worlds the phenomena are constituted in a specific manner and in a certain shape. However, the social construction of friendship is dependent on basic principles of constituting the subjective consciousness. For the present analysis, several typical principles of the construction of friendship will be illustrated-each independent of the socio-historical context-which will serve as stimuli for the analysis of several constitutive principles of friendship. It is of crucial significance here that friendship is primarily symbolically constructed, i.e. that it is formed by means of constructive processes based on a collectively shared symbolism with a repertoire of culturally defined categories.

In the following, three protosociological stages of reduction ${ }^{6}$ will be drawn up, which will enable us to describe the constitution of the phenomenon of friendship. Analogous to the strictly egologically oriented phenomenological method of reduction (Husserl 1913/1982, §56ff.), which is adapted to the analysis of the constitution of social phenomena, the protosociological reductions are aimed at the exposure of several basic prerequisites for this form of social relationship. Phenomenological reductions aim to expose general "formal" structures of experience which exist in sequences of the human consciousness. The most obvious of these structures are the categories of subjective orientation in space, such as "above/below," "in front of me/behind me" and the rhythms of internal time. It is more difficult to grasp the life-world structurization of social relationships, which are graded according to degrees of immediateness, familiarity, and anonymity (Luckmann 1999/2007, p. 130). The following three levels of reduction in terms of protosociology ${ }^{7}$ are presented here.

\footnotetext{
${ }^{6}$ Here, additional reductions with regard to the constitution of friendship could be elaborated on, dependent on the respective "bracketing" of semantic contexts; the analysis in the present study is restricted to three levels of constitution.

${ }^{7}$ Following Thomas Luckmann, I use the term "protosociology" in relation to a phenomenological description of the epistemological foundations of the social sciences (Luckmann 1973/1983a, p. 69f.). Protosociology concentrates on the analysis of the general structures of the life-world that are considered to be a "mathesis universalis" (Luckmann 1973/1983b, p. 25ff.). For the analysis of concrete social phenomena I apply the concept of protosciology for the socio-eidetic reduction describing the empirical
} 
Socio-Eidetic Reduction of the Construction of Friendship

Following Husserl's reflections on "eidetic reduction" and his considerations of the methodological orientation of psychology allows us to challenge specific problems of the social sciences. Husserl defines psychology as an empirical science that concentrates on "facts" and "realities." The phenomena which it deals with as psychological phenomenology are understood to be real events, which—if they truly exist - can be assigned to real subjects, to which they belong, as part of a spatialtemporal world (Husserl 1913/1982, p. xviif.). By contrast, transcendental phenomenology is not a science of facts but rather a science of being, for which "facts" as such are not relevant. The related reduction, which transfers us from the psychological phenomenon to the pure "being," or in judgment-oriented thinking from the actual (empirical) universality to the universality of being, is the above mentioned "eidetic reduction." Along a similar line, the social sciences must be understood as empirical sciences that use the concrete empirical properties of social phenomena for the development of typologies for the construction of them. What is now decisive with regard to conducting a socio-eidetic reduction of the construction of friendship is a description of the typical properties of this phenomenon. As for Husserl, the eidetic reduction is preceded by an "eidetic variation" (Husserl 1929/ 1969, Chap. 7) with regard to a sphere of possibility of the occurrence of the phenomenon. For the sake of socio-eidetic reduction, the different properties of friendship are presented in different historical epochs and cultures - in a rudimentary manner in this framework.

Along these lines, several typical properties of the construction of friendship in different epochs will be illustrated from the perspective of sociology of knowledge; a comprehensive, trans-cultural presentation is not possible in this study. This approach enables us to determine what concrete properties of friendships can be found empirically in socio-historical contexts and with what semantic contents. What is the specific nature of the forms of relations manifested in various cultural contexts which one can conceive as friendships? To give a few examples, eighteenth century Germany is associated with an eternal antinomy of the modern spirit of creation, achievement, and work, on the one hand, and life, spirit, and soul, on the other hand, and a decision for one of these dispositions is demanded. The "amicable community" (freundschaftliche Gemeinschaft) that emerged in that socio-historical context becomes the symbol of the battle of the soul and its absolute demands against the "lethargic and tenacious substance of life" (Salomon 1921/1979, p. 289). The concretizations of friendships penetrate into human life as the "pure reality of the soul" and take on an existential status for their existence.

From an ideal-typical point of view, Albert Salomon distinguishes among three different forms of friendship-based relationships in eighteenth century Germany, which in turn are associated with three periods with corresponding ways of life. The humanistic cult of friendship which defines these epochs has two origins. It dates

Footnote 7 continued

(historical and cultural) variations of the phenomenon as well as for the phenomenological reductions investigating the constitution of the social phenomenon, in our case friendship. 
back to the formative background of the ancient world and to the idea of a union of men in awareness of service to the valuable good of classical education.

In the first phase friendships are still embedded in a general gregariousness, as this is an epoch of inner harmony of the Enlightenment and the German Rococo ${ }^{8}$ period; the Enlightenment is still in a static form. Men of letters such as Johann Georg Jacobi, Christian Felix Weiße, Christian Fürchtegott Gellert, Gottlieb Wilhelm Rabener and Christoph Martin Wieland ${ }^{9}$ put into words the specific ways of life that are to be understood as a product of common sense in the service of humankind. Human society therefore takes on the form of gregariousness which matches its purpose. This society is held together by human kindness, which reaches its highest and purest form in friendship (Salomon 1921/1979, p. 297).

The second epoch is marked by the development of unions of friendship between young people, who counter the now empty forms of Rococo culture with a new feeling and attempt to break them down, but do not yet establish any new ways of life for demarcation purposes. Representatives of this epoch are Johann Wolfgang von Goethe, Jakob Michael Reinhold Lenz, and Friedrich Leopold zu StolbergStolberg, ${ }^{10}$ in their youth, who condemn Wieland as the most significant representative of German Rococo due to his pathos and emotionalism. For them, friendship becomes the main problem of personal life; it is the form that alone can overcome the chaos of the young men of letters. These friendships are marked by a paradoxical interlocking of the most profound proximity and distance at the same time. Individuality becomes an increasingly integral component of this type of relationship.

In a third epoch in the classical period, following romanticism, we can identify a synthesis of both forms, which generates a mental union in which creative and productive humans experience friendship as the completion of education, as a necessary form in order to achieve human totality (Salomon 1921/1979, p. 292ff.). For these types of relationships, eros is desire without coercion and strives in an intelligible world for the idea of the complete design-friendship is love as unlimited devotion. As examples for this period, we can cite the personal friendships between Johann Wolfgang von Goethe, Wilhelm von Humboldt, Johann Christoph Friedrich von Schiller and Christian Gottfried Körner ${ }^{11}$ in which humanity found an expression. The conviction that friendship can only exist among the noble, which already can be found in Nicomachean Ethics (Aristotle 2002), finds

\footnotetext{
${ }^{8}$ Rococo refers the epoch of early Enlightenment still highly influenced by the Baroque period. It focused on subjective emotionality and sensitivity, but at the same time emphasized the individual, rationally founded world of experience.

9 Johann Georg Jacobi (1740-1814), Christian Felix Weiße (1726-1804), Christian Fürchtegott Gellert (1715-1769), Gottlieb Wilhelm Rabener (1714-1771) and Christoph Martin Wieland (1733-1813) were literary authors of the early German Enlightenment.

10 Johann Wolfgang von Goethe (1749-1832), Jakob Michael Reinhold Lenz (1751-1792), Friedrich Leopold zu Stolberg-Stolberg (1750-1819) in their younger years were representatives of the Sturm und Drang (Storm and Stress) period.

11 Wilhelm von Humboldt (1767-1835), Johann Christoph Friedrich von Schiller (1759-1805) and Christian Gottfried Körner (1756-1831), together with Goethe, were involved in these kinds of friendship during the later period of the German Enlightenment.
} 
expression in the works of Cicero and is of great significance for the classical era (Salomon 1921/1979, p. 303f.).

For modern, differentiated societies the thoughts of Georg Simmel are crucial. He describes the particular modern type of friendship in which the extent of intrusion or reservation is pivotal in a friendship-based relationship. With one person we share a common mindset, with another we share spiritual similarities, with a third religious experiences, and with a fourth person common experiences. In such friendships the friends are not called onto look into each other's interests and feelings, "which, after all, are not included in the relation and which, if touched upon, would make them feel painfully the limits of their mutual understanding" (Simmel 1908/1964, p. 326). Although these friendships are limited in a certain way, the relationship is indeed experienced from the inside of the entire personality. According to its fundamental ideal, it leads to the same depth of the soul and the same willingness for sacrifice that can be found in other epochs.

As ideal types, several different properties of friendship could be labeled and reconstructed. A comprehensive, trans-cultural description of emerging types of friendships ${ }^{12}$ would be the task of a large-scale study which cannot be carried out here and now. The following common features with regard to the construction of friendship are recognizable: certain empirically manifested principles of the constructions of this form of relationship exist—as already shown-in a personal, free decision of the individual to engage in the bond with the other person; the relationship is normally not based on a sexual bond; in all cases the involvement of the ego of the individual friend can be ascertained and frequently the friend achieves an existential status by being incorporated into the living circumstances of his or her counterpart. Common interests, which also impact the definition of friendship, can vary. They can relate to ideals from the ancient world, the Roman Empire, classical education, humanism, religious orientations, etc., but in terms of structure, the properties of friendships are very similar. The specific feature of friendship consists in the fact that, in comparison to a love relationship, no physical attraction must exist within the social relationship. Friendships can exist between older and younger people; differences in sex do not necessarily constitute an obstacle for friendships, socio-structural boundaries can be overcome by friendship and, moreover, friendships between individuals with completely different cultural backgrounds are conceivable.

It is a highly personal and individual decision whether a person is recognized as a friend or not. The we-relationship itself, according to Alfred Schutz, transcends the existence of each of the partners within the paramount reality of everyday life and can only be grasped or "appresented" 13 by symbols. To each of us, my friend and I are elements of the world of everyday life in which we communicate with each other. However, our friendship as an idea exceeds our individual situation within the

\footnotetext{
${ }^{12}$ For example, with regard to the US-American understanding, the concept of friendship is used in a less demanding manner and the closeness and duration of the social relationship decisively differs from the European form so that we can speak of a "less binding comradeship" (Schelsky 1957, p. 351ff.).

13 "Appresentation" or "analogical apperception" refers to doubling as an integral part of activities of the consciousness, in which for example in processes of perception the emerging object triggers or brings to mind a different, non-present circumstance (Schutz 1962, p. 294ff.).
} 
closed sphere of meanings of the paramount reality. The everyday transcendent idea of a unique friendship cannot be easily expressed with the words of our everyday life. As I will demonstrate, it is an idea established through symbolization. The concept of the we-relationship comprises all degrees of intimacy and strangeness, and therefore the symbols by which the we-relationship is grasped are of a highly different nature. Their appresented link is always the common situation, as defined by the participants, i.e. their common experience, their mutual utility, their shared suffering and joys. A common interest makes them partners and the idea of partnership is the general expression for the appresented we-relationship. We are lovers, fellow sufferers, colleagues, comrades, etc. (Schutz 1989, p. 292). Once the friendship is established on the basis of an everyday transcendent idea, the two individual persons in their specific we-relationship function as symbols for this particular, unique idea of friend; they stand for and symbolically appresent this everyday transcending idea of the specific friendship which hardly can be grasped with words.

A constitutive circumstance for the phenomenon is that when the biographies of two individuals intersect one another, the common experience takes on an existential character for both friends and both retrospectively identify this experience with the idea of friendship that transcends everyday life. The idea of friendship itself, which retrospectively always is temporally distant to the existentially important encounters on which it is based and is shared by both partners, belongs to a non-everyday reality as a notion of a "unique bond" between two people. The friend is a fundamental part of the everyday reality in which we act; it is now decisive that the union of these two people-their togetherness-symbolizes the idea of friendship for the respective other, i.e. typifies the special, unique relationship between the friends. In the moment in which the social relationship is symbolized, it is constitutive for the development of the phenomenon of friendship and grants this form of relationship its existential status. The fact that the person I communicate and associate with in everyday life is considered to be a friend depends on mutually shared everyday transcending ideas that are related to our unique friendship. The commonly experienced everyday transcendent reality of friendship that is symbolized has repercussions on the encounter of the two persons in everyday life. We are not just fellow human beings any more-we are friends!

Friendship is fortified by concrete shared experiences of the partners, which form the quasi substantial basis of the social relationship. These can be experiences related to common creative activities, shared traveling experiences, adventures, sport achievements, overcoming crisis situations, etc.; in other words, experiences to which a particular character is retroactively attributed by both friends. Such stories are frequently told time and time again in a ritual-like manner in order to symbolically keep the friendship alive and make it long-lasting. However, these narrations are by no means indispensable for the constitution of friendship, because the social relationship can also be long-lasting without them, if the friendship as an idea lives on in memory in what I call its symbolic auxesis. The narrations belong to the everyday life-world and pertain to the non-everyday idea of friendship. Retelling them in a ritual-like manner evokes the emotional fondness for the friend time and 
time again. With the narrations, the symbolized we-relationship reverts back to everyday life, having the effect that the individuals base their everyday actions on social relationships established by these means.

\section{Structural Level of the Symbolic Constitution of "Friendship"}

If the culturally defined and empirically manifested categories associated with friendships are now "bracketed" for the second protosociological reduction, we can describe specific structural circumstances. Life-world based principles for constituting "friendship" become apparent, which show that both participants in the social relationship must share with the other person the memory of the uniqueness of the relationship, as well as experiences of an existential nature, which hold an outstanding status in the biography of the individual. The duration of the relationship is definitive, although the time dimension becomes irrelevant as a boundary depending on the degree of development of the friendship. The social relationship must be consistent, so it goes without saying that it can always be rekindled. In an ideal situation, the spatial distance between the friends does not have to derogate from the relationship. Mutually confided trust results from an assumed familiarity with the other person, and thus creates intimacy within the relationship. Both persons must be able to symbolize and hence objectivize shared experiences, ideas, and the friendship itself as an idea. Its extreme form-the idealized and overstated "eternal friendship" - can have the potential to overcome boundaries within the social world that exist between the individuals and are systematically "bracketed" in their concrete development for the second level of reduction. Generation, gender, status, class, culture, etc. as structural features of social circumstances can be overcome with the emergence of the phenomenon of friendship. As a rule though, friendships occur much more frequently within the relevant social groups and environments.

The symbolic auxesis, that is to say the superelevation through symbolization of the social relationship, definitely includes its emotional reinforcement by the affection that the friends show towards each other. The symbolic overcoming of the transcendence of the other within a friendship and the symbolic reference to the shared idea of friendship make this social relationship long-lasting without this having to be continuously communicated: "the symbol establishes communion without communication" (Jaspers 1973, p. 24f.). The friendship becomes a phenomenon of life by means of symbolization and takes on the mentioned existential character, i.e. it becomes an emotionally reinforced component of the personal identity of the individual. The friend thereby becomes an integral component of the intersubjective life-world of the individual, as the individual defines him/herself through the friend, while his/her ego is "reflected" in that of the friend, the symbolically superelevated other. This process leads to mutual reflections on the particular individuality of the single person, who attains his/her uniqueness by means of the friend, so to speak. The constitution of friendship creates a bond between two individuals with which the intersubjectively established boundaries of space, time, and social structure can be overcome. This existential form of relationship results from the capacity of the experiencing and acting subject 
for symbolization, which is defined epistemologically and with which a "unique" social relationship can be objectivized.

Along these lines, symbols contribute to making non-everyday worlds of meaning intersubjectively experiencable, i.e. collectively "accessible"; furthermore, politically, religiously, aesthetically, scientifically, and in the broadest sense culturally defined spheres of reality, to which friendship can be added, are simultaneously constituted only on the basis of the continual use of symbols in social contexts. What is now essential for the description of the second protosociological level of reduction is that "friendship" can be symbolically constituted as a form of relationship on the basis of the structure of the life-world of the acting subject-in particular, with regard to their division into an everyday world and diverse realities. The structural moment of the symbolic establishment of this form of relationship explains, in particular, the perpetuity of friendship, which does not necessarily rely on sensuality. Friendships are carried by the symbolically constituted world of meaning, which develops in the bond between the friends and in which the "idea of a unique friendship" is defined.

\section{Level of Reduction of the Sensual Perception of the Living Body of the Other}

The living human body of individuals takes center stage in the third protosociological level of reduction. This living body is involved in the encounter between both partners, which is still marked by cultural codes as well as the structural moment of symbolization at the previous levels. This level of abstraction of the sensual perception of the living body of the other is reached subsequent to the socioeidetic reduction and the structural level of the symbolic constitution of friendship. It pertains, in particular, to the description of the meaning of the face-to-face situation. Here it is decisive how the living body of the other is perceived. The central theme is supposed to be the formal level of the encounter with the other, on which the intentionality of the subjective consciousness constitutes the counterpart as another person, to which is attributed a distinctive meaning. One subjective perception of the other is given typically as "strange" and "familiar," "anonymous" and "immediate," whose image is conceived as strange or familiar. Language and semiotic symbolic references are "bracketed" for this level of reflection; a pre-theoretical, pre-linguistic level of the bodily encounter ${ }^{14}$ may be analyzed with regard to its relevance for the constitution of friendship.

As a rule, it must be understood that intersubjectivity with regard to the development of the ego of the individual assumes an antecedent position and to this extent cannot be explained in transcendental-phenomenological terms. According to Schutz, intersubjectivity is considered to be a problem which cannot be solved within the transcendental sphere; rather it is a problematic to be investigated in

\footnotetext{
${ }^{14}$ It is beyond question that the level of reduction presented here cannot reach transcendental subjectivity as pointed out in the description of Husserl's thoughts on phenomenological reduction. In focusing on the social phenomenon of friendship, the perception of the Other still has to be part of the reduction procedures and it is not necessary to thematize transcendental subjectivity. Nevertheless we have to emphasize that any encounter with the Other is based on constitutive processes of transcendental subjectivity.
} 
relation the life-world (Schutz 1957/1966). Intersubjectivity is understood to be the basic ontological category of human existence and thus of all philosophical anthropology. The possibility of reflecting on oneself, the discovery of the ego, the ability to carry out every epoché but also the possibility of any type of communication, are based on the primordial experience of the we-relationship (Schutz 1957/1966, p. 82). Even though we agree with Schutz, for the third reduction carried out in this section, his assumptions can be disregarded in methodological terms. They need to be "bracketed" in order to-still dependent on these assumptions - describe the basic principles of the encounter with the other and hence the constitution of friendship as a form of relationship. To reach the level of the sensual perception of the living body of the Other, a pre-stage of the constitution of the we-relationship can be identified.

We as the subjects of our living-in-the-world, of our activities, with our habitual interests and aims, who are bound in relationships of "for-each-other," "againsteach-other," or "with-each-other" build an entity of those bounds with each other because of common interests (Husserl 2008, p. 385). ${ }^{15}$ The life-world is described as the world-surrounding-us which includes fellow human beings who can be differentiated into spheres of distance and closeness. All objects, everything surrounding us and everything which is part of my field of interest from the outset, are within the horizon of my fellow human beings. They are subjects of interest, they have a surrounding world centered around them which is considered to be their field of interest. This field of interest includes everything which is practically relevant or irrelevant and practically within our thematic focus in relation to our acting and working (Husserl 2008, p. 386). To me, my fellow human beings are not only in the surrounding world, they are family members or non-members, relatives or non-relatives etc. In relation to this analysis, these fellow human beings according to the interest structure of the surrounding world as part of the life-world and dependent on closeness, familiarity or intimacy, may come to be considered as "friends." As individual fellow humans beings they appear within the horizon of the surrounding world in which the familiarity between ego and alter ego is established.

Along these lines, the other is conceived as another human, while in the encounter, the body of the other is perceived as analogous to one's own for the constitution of the phenomenon of friendship. ${ }^{16}$ Everything that is not perceived as "not one's own" in the encounter with the other is conceived as belonging to the other. A transfer of meanings takes place between ego and alter, in which degrees of similarity can be developed according to the mode of being time-tested and not time-tested. Furthermore, these transfers of meanings are responsible for the peculiar familiarity with the counterpart, who is chosen to be a friend in a symbolization of the

\footnotetext{
15 The recently published works of Edmund Husserl with a focus on "the life-world"("Die Lebenswelt", Husserliana XXXIX: Die Lebenswelt. Auslegungen der vorgegebenen Welt und ihrer Konstitution) reveal insights closely related to what is defined as protosociology. His reflections on "the life-world as personal world of praxis"describe association of human beings, intentional communities, as the major topic of "intentional sociology" (Husserl 2008, p. 389).

${ }^{16}$ Pen-pal relationships and Internet chat friendships, which manage without the face-to-face encounter with the friend, will not be addressed here, because we can assume that they profit from or seek to elude the notions of friendship defined by ideal-types and resulting from physical encounters.
} 
relationship. They form the basis for the constitution of sympathy resulting from the encounter with the living body of the other and which characterizes the phenomenon of friendship. When speaking of friendship in a culturally coded manner as "love as unlimited devotion," it must be kept in mind that this statement has its origins in the bodily encounter, in which the particular familiarity with the friend is constituted. The fact that friendship is typically expressed by the gesture of embracing is motivated by the physical encounter. The level of physical encounter with the other is described here. However, the phenomenon of friendship in its ideal-type, in its longlasting form on the basis of a symbolic auxesis, relies less on the physical constitution than the phenomenon of love.

A phenomenological and social science parallel action could serve to define several basic principles of the construction and constitution of friendship, which nevertheless make no claim to universal validity. The findings of an empirical science-sociological reflections on the construction of friendship-are confronted with phenomenological, or more precisely, protosociological considerations, which are carried out with regard to a social phenomenon and concretize the constitution of the phenomenon of friendship. A corrective function can be attributed to this parallel action, which took advantage of several interfaces between both strands of research. Each discipline becomes the corrective for the other: phenomenology gives the sociology of friendship decisive clues on the epistemological foundations of the construction of this phenomenon. The phenomenological, protosociological descriptions of the constitution of friendship are guided in a certain direction by the empirically manifested, ideal-typically reconstructed sociological findings on friendship and highlight the boundaries of the analysis of constitution.

\section{References}

Aristotle (1992). In M. Woods (Ed.), Eudemian ethics: Books I, II, VIII. Oxford, New York: Oxford University Press.

Aristotle (2002). In C. Rowe \& S. Broadie (Eds.), Nicomachean ethics. Oxford: Oxford University Press. Berger, P. L. (1993). A far glory. The quest for faith in an age of credulity. New York: The Free Press. Berger, P. L., \& Luckmann, T. (1966/1987). The social construction of reality. A treatise in the sociology of knowledge. Harmondsworth: Penguin.

Cooper, J. M. (1977). Aristotle on the forms of friendship. The Review of Metaphysics, 4(120), 619-648.

Dreher, J. (2003). The symbol and the theory of the life-world: The transcendences of the life-world and their overcoming by signs and symbols. Human Studies, 26(2), 141-163.

Dreher, J. (2008). Protosoziologie der Freundschaft. Zur Parallelaktion von phänomenologischer und sozialwissenschaftlicher Forschung. In J. Dreher, M. Pfadenhauer, J. Raab, et al. (Eds.), Phänomenologie und Soziologie. Theoretische Positionen, aktuelle Problemfelder und empirische Umsetzungen (pp. 295-306). Wiesbaden: VS.

Eberle, T. S. (Ed.). (2000). Schütz' Lebensweltanalyse: Soziologie oder Protosoziologie? In Lebensweltanalyse und Handlungstheorie. Beiträge zu einer Verstehenden Soziologie (pp. 55-79). Konstanz: UVK.

Helm, B. (2005). Friendship. In E. N. Zalta (Ed.), Stanford encyclopedia of philosophy. Retrieved September 30, 2009, from http://plato.stanford.edu/entries/friendship/.

Husserl, E. (1913/1982). In F. Kersten (Ed.), Ideas pertaining to a pure phenomenology and to a phenomenological philosophy. Vol 1: General introduction to a pure phenomenology. The Hague: Nijhoff. 
Husserl, E. (1929/1969). Formal and transcendental logic (D. Cairns, Trans.). The Hague: Nijhoff.

Husserl, E. (1936/1970). The crisis of European sciences and transcendental phenomenology (D. Carr, Trans.). Evanston: Northwestern University Press.

Husserl, E. (2008). In R. Sowa (Ed.), Husserliana XXXIX: Die Lebenswelt. Auslegungen der vorgegebenen Welt und ihrer Konstitution. Dordrecht: Springer.

Jaspers, K. (1973). Philosophie III. Metaphysik. Berlin: Springer.

Kracauer, S. (1971). Über die Freundschaft. Frankfurt: Suhrkamp.

Luckmann, T. (Ed.). (1970/1983). On the boundaries of the social world. In Life-world and social realities (pp. 40-67). London: Heinemann.

Luckmann, T. (Ed.). (1973/1983a). Elements of a social theory of communication. In Life-world and social realities (pp. 68-91). London: Heinemann.

Luckmann, T. (Ed.). (1973/1983b). Philosophy, science, and everyday life. In Life-world and social realities (pp. 3-39). London: Heinemann.

Luckmann, T. (1983). Eine phänomenologische Begründung der Sozialwissenschaften? In D. Henrich (Ed.), Kant oder Hegel? Über Formen der Begründung in der Philosophie. Stuttgarter HegelKongreß 1981 (pp. 506-518). Stuttgart: Klett-Cotta.

Luckmann, T. (1991). Protosoziologie als Protopsychologie? In M. Herzog \& C. F. Graumann (Eds.), Sinn und Erfahrung. Phänomenologische Methoden in den Sozialwissenschaften (pp. 155-168). Heidelberg: Asanger.

Luckmann, T. (1999/2007). Wirklichkeiten: individuelle Konstitution und gesellschaftliche Konstruktion. In J. Dreher (Ed.), Lebenswelt, Identität und Gesellschaft. Schriften zur Wissens- und Protosoziologie (pp. 127-137). Konstanz: UVK.

Musil, R. (1995). The man without qualities (Vol. 2). New York: A.A. Knopf.

Psathas, G. (1973). Phenomenological sociology. Issues and applications. New York: Wiley.

Psathas, G. (1989). Phenomenology and sociology. Theory and research. Boston: University Press of America.

Salomon, A. (1921/2008). Der Freundschaftskult des 18. Jahrhunderts in Deutschland. In P. Gostmann \& G. Wagner (Eds.), Werke 1. Biographische Materialien und Schriften 1921-1933: 9Bd. 1 (pp. 81135). Wiesbaden: VS-Verlag.

Salomon, A. (1921/1979). Der Freundschaftskult des 18. Jahrhunderts in Deutschland: Versuch zur Soziologie einer Lebensform. Zeitschrift für Soziologie, 8(3), 279-308.

Schelsky, H. (1957). Die skeptische Generation. Düsseldorf: Diederichs.

Schutz, A. (1932/1997). The phenomenology of the social world. Evanston: Northwestern University Press.

Schutz, A. (1945/1962). On multiple realities. In M. Natanson (Ed.), Collected papers, vol. I. The problem of social reality (pp. 207-259). Den Haag: Nijhoff.

Schutz, A. (1957/1966). The problem of transcendental intersubjectivity in Husserl. In I. Schutz (Ed.), Collected papers III: Studies in phenomenological philosophy (pp. 51-84). The Hague: Nijhoff.

Schutz, A. (1962). Symbol, reality and society. In M. Natanson (Ed.), Collected papers, vol. I. The problem of social reality (pp. 287-356). The Hague: Martinus Nifhoff.

Schutz, A. (1989). Appendix: The notebooks. In A. Schutz \& T. Luckmann (Eds.), The structures of the life-world (Vol. 2, pp. 159-324). Evanston: Northwestern University Press.

Sherman, N. (1987). Aristotle on friendship and the shared life. Philosophy and Phenomenological Research, XLVII(4), 589-613.

Simmel, G. (1908/1964). In K. H. Wolff (Ed.), The sociology of Georg Simmel. New York: Free Press.

Soeffner, H.-G. (Ed.). (2000). Zur Soziologie des Symbols und des Rituals. In Gesellschaft ohne Baldachin. Über die Labilität von Ordnungskonstruktionen (pp. 180-208). Göttingen: Velbrück.

Srubar, I. (1988). Kosmion. Die Genese der pragmatischen Lebensweltheorie von Alfred Schütz und ihr anthropologischer Hintergrund. Frankfurt: Suhrkamp.

Tenbruck, F. H. (1964). Freundschaft. Ein Beitrag zu einer Soziologie der persönlichen Beziehungen. Kölner Zeitschrift für Soziologie und Sozialpsychologie, 16, 431-456.

Tönnies, F. (1887/2001). In J. Harris (Ed.), Community and civil society. Cambridge: Cambridge University Press. 